International Journal of Instruction e-ISSN: 1308-1470 • www.e-iji.net
July $2019 \bullet$ Vol.12, No.3

p-ISSN: 1694-609X

pp. $271-288$

Received: 05/12/2018

Revision: 24/03/2019

Accepted: 01/04/2019

OnlineFirst:29/04/2019

\title{
Students' Perception of Learning Experience and Achievement Motivation: Prototyping English for Academic Purposes (EAP)
}

\author{
Khoirul Anwar
}

University of Muhammadiyah Gresik, Indonesia, khoirulanwar@umg.ac.id

\section{Agus Wardhono}

University of Ronggolawe Tuban, Indonesia,agusward@gmail.com

There are two prominent constraints of students' needs analysis; first, the identification of needs in teaching English for Academic Purposes (EAP) merely focuses on two main dimensions, namely target needs and learning needs, and less to involve affective factors as the basis of all (including learning experience and achievement motivation). Second, there is a common notion that EAP learning is considered the same as general English so that the development of learning design often leads to English for General Academic Purposes (EGAP). This study aims to identify students' perception of learning experience and motivation for the prototype of learners' needs of English for Academic Purposes (EAP) in Industrial engineering. Data were collected from 40 students using three types of questionnaires, namely about learning experiences, learning motivation, and learners' needs. The data of learners' needs was also taken from 8 lecturers as well as program managers. By using quantitative and descriptive analysis, this study showed that first, the students had reasonable learning experience, by being able to participate in the EAP program. Second, the students had strong motivation in achieving their goals. Third, the relationship between learning experience and achievement motivation was not significant and was not quite strong, implying that learning experiences were predicted not to affect students' learning motivation. Fourth, the students' needs lead to English for Specific Academic Purposes (ESAP) which is thus contradictory with the previous notion.

Keywords: learning experience, achievement motivation, prototyping, students' perception, prototyping English

\section{INTRODUCTION}

There are three essential concerns in the implementation of English for Academic Purposes (EAP), namely learning objectives, program managers, and learners' expectations (Robinson, 1991). All three must be incorporated into a program planning

Citation: Anwar, K., \& Wardhono, A. (2019). Students' Perception of Learning Experience and Achievement Motivation: Prototyping English for Academic Purposes (EAP). International Journal of Instruction, 12(3), 271-288. https://doi.org/10.29333/iji.2019.12317a 
that is able to describe the all-encompassing integration of interests so that EAP learning can yield satisfactory outcomes. This process of finding the amalgamation from various wishes or expectations to be met is a challenge in designing EAP in one that many parties often consider as difficulties. Differences in expectations and "wish-lists" from learners, managers, and goals are very diverse so that an in-depth analysis is required to reflect the needs of all parties involved. This is certainly very different from English for General Purposes (EGP), where there are many similarities in objectives and connections in the needs of learners so that the material content can be designed more quickly with a high degree of flexibility (Asmara, Anwar, \& Ribeh, 2016).

EAP identification of needs is still a significant concern in the presentation of this paper at least for three reasons namely the extraordinary role of researchers who have authoritative decision in the needs analysis process where accuracy must be raised as well as to reduce subjectivity if possible by complementing affective aspects in the need analysis (Alastal, 2012). This affective factor is rarely associated with the findings of needs analysis, especially those relating to the background, interests, and motivation of EAP learners. All the needs analysis process is still merely fixed on two important points - the target needs and learning needs (Hutchinson \& Waters, 1987). Therefore it is necessary to expand the scope of this analysis by including affective aspects because the emotional factors of the learners also play an important role in the success of learning (Dornyei, 1994). Secondly, needs analysis largely determines the shape and characteristics of learning in a specific field of study, so the effort to ensure EAP prototype of English language needs for each group of study areas is certainly challenging (Berwick, 1989). Determining the uniqueness and specificity of the needs of each field which is an endless challenge for each EAP designer including the integration between cognitive and affective learning facets, are equally important. Third, there is a dominant direction of EAP learning up to now which leads to general specific purposes. Consequently, many EAP studies are critical to prove further direction of EAP position currently and in the future, given the changing needs of EAP learners are mounting and unpredictable (Hamzaoui-Elachachi \& Graia, 2014).

Therefore, this study aims to identify the target needs and learning needs of cognitive, learning experience, and students' learning motivation. In addition, this study also aims to identify the relationship between learning experience and achievement motivation for EAP students in the engineering faculties of two universities, namely the University of Muhammadiyah Gresik and University of PGRI Ronggolawe Tuban.

\section{LITERATURE REVIEW}

\section{Need Analysis}

A need analysis is the first step that really determines the material content and learning strategies that will be carried out, which includes identifying the expectations and wishes of prospective learners (Alastal, 2012). All materials developed must adjust the level of these wishes and expectations so that the implementation of EAP can be carried out successfully. The success of this process forms the main determining capital in designing the next stage, namely the development of teaching materials equipped with learning strategies and media (Conole, 2013). 
In the context of EAP learning, the instructors and the designers of syllabus and learning materials must naturally be able to work well together and understand each other to proceed at all stages to achieve accountable final goals. This must be done because the needs analysis always provides a special portrait for each group of learners in accordance with their background. The portrait can be in the form of learning arrangements, experiences and assessment, psychological, sociological, and methodological needs, language functions, and students' attitudes (Chan \& Chen, 2012; Elachachi and Graia, 2014; Christison and Krannke, 1986; Clowes, 1994; Howell, 1995; Thi Hong, 2018;My Lien,2009). Thus the results presented from the process of identifying needs analysis must be explained objectively and scientifically, even though the opportunities for subjectivity are also very high. Moreover, at the level of learning implementation in the classroom, instructors and program designers must also be involved as insiders and as facilitators who are ready to conduct intensive evaluations to monitor weaknesses (Asmara, Anwar, \& Ribeh, 2016).

Because the needs analysis is always considered a salient and strategic first step in ESP learning design, the essence of the procedure must be carefully and thoroughly pondered. The process of this needs analysis must begin with an assessment that focuses on the learner and the other parties involved (including stakeholders) in the EAP program, such as the program head and the instructors, for example. The assessment process can be carried out with both qualitative and quantitative instruments as long as they fulfil the elements of validity and reliability adequately (2016).

In general, a needs analysis can be grouped into two, namely goal-oriented assessment and process-oriented assessment. This goal-oriented need assessment includes identifying needs about the level of learner's language skills, the scope of the material both related to its breadth and depth to reflect the learning objectives. Whereas processoriented English needs assessment must be related to the strategies and efforts of learners to achieve their learning competencies (Brindley, 1989). This learning strategy is often related to approaches, methods, learning techniques needed by learners and types of evaluations that are in accordance with their character to achieve the goals and competencies. Furthermore, other parts are needed to achieve a maximum result of the process, namely optimal learning media and conditions or a supportive learning atmosphere. Two emphases on the assessment model of the needs analysis above are similarly categorized into two large groups, namely the target needs and learning needs (Hutchinson \& Waters, 1987). The former relate to what must be learned, and are divided into three parts namely wants, necessity, and lacks. Wants encompass all learners' wishes and expectations of EAP, Necessities include all target learners that should be needed in EAP, while Lacks are gaps or ranges that must be filled between targeted expectations and the reality of current capabilities. On the other hand, learning needs relate to how learners learn, which is naturally in line with materials, strategy, and learning atmosphere. These two points offered by Hutchinson and Waters have reinforced the previous opinion despite using different terms but agree that the needs analysis should be made correctly and scientifically (Hutchinson \& Waters, 1987). Thus learning needs can help trace the factual learning process by considering learners' expectations in terms of delivering goals and methods, the materials, the place and time 
expected, and the evaluation model to be used. At this point, Widowson and Hutchinson (1981) have similar phases in carrying out this type of needs analysis.

Even Berwick (1989) argues that essential processes in needs analysis are the ability to identify between gaps or differences that are learned and which should be studied. What is learned is related to all the learner's knowledge that has been possessed while what should be learned is related to the ultimate goal of the expected learning situation. The process of needs analysis must be carried out carefully because all researchers can be trapped into the subjectivity of the findings so that it impacts on factual conclusions. Besides, the learning subject that is being identified can influence the analysis process depending on the complexity and diversity of findings (Robinson, 1991). Each finding must have a uniqueness that represents the subject or learners being analyzed, therefore researchers have a very crucial role in drawing conclusions without being influenced by their subjectivity (Clowes, 1994), although researchers have a fairly dominant space in decision making. This mapping of learning goals is the point of reference in directing the objective and attitude of the researcher (which is considered as a weakness in needs analysis)

Definitely, learning goals are grouped into two important areas, individual and social goals. Alderson divides these goals into four categories, namely formal needs, actual needs, future needs, and learner needs. Formal needs are usually synonymous with learning efforts to fulfil the institution's wishes and targets, for example, wanting to get good grades or pass certain subjects. Actual needs are real needs where learners are able to identify learning needs according to the demands of reality (Alderson, 1980). Future needs are all learners' desires in fulfilling their career development and professionalism. While the needs of students are the desires and expectations of learners in following the process that will be carried out. These four entities can be concluded in major needs which are often referred to as social and educational aspects. Social needs are often related to the interest of English in macro matters, for example, English as an international language, English for General Purposes, English for Specific Fields, English for cultural Communication etc., while educational is related to needs which include interest in material stuffs, methods, media, and learning environments (1980).

Practically, needs analysis can be further divided into two very essential categories, namely objective needs and affective needs. Objective needs can be categorized as for where the previous opinion is, namely the analysis of needs related to what will be learned by learners including the previous abilities, language skills that have not been mastered, media and chosen learning methods, and evaluation tools that can be applied. Even the EAP learning media and assessment must be able to meet the needs for the use of information technology which is currently developing and is in great demand by learners of English (Dashtestani \& Alavi, 2014; Estaji, 2018; Machmud, 2018). Meanwhile, effective needs are learning expectations that are characteristic of students in the form of attitudes, interests, motivations, and preferences in learning. Because these two items are complementary, and rigid identification must be completed comprehensively and thoroughly (Kuh, 2009). 


\section{The Importance of Affective Factors in Need Analysis}

Affective factors are crucial for the success of needs analysis especially about students' learning experiences and achievement motivation. The learning experience has a strong influence on the next learning process because it is related to the learner's individual interaction with the learning environment where he/she responds to all stimuli to come. In this context what is done by students is actually far more important than what is prepared by the teacher. Therefore, Caswel and Campbell in Kharma (1988) argue that the syllabus or curriculum must be developed and compiled to provide all the best experiences of students through teacher guidance. They further require learning experiences that fulfil the following aspects: referring to learning interactions that optimize external conditions, and the realization of learning interactions through students' active behavior. Thus the past learning experience and students' motivation in learning EAP are very useful to be used as a benchmark in designing future English learning activities (Kharma, 1988; Johnson, 2012).

The next affective aspect which is also very important to consider in EAP needs analysis is student learning motivation (Anwar \& Arifani, Task Based Language Teaching: Development of CALL, 2016). Learning motivation is the encouragement that is driven internally and externally to each individual reflected in learning behavior. The reflection of the attitude that represents learning motivation is usually the desire to succeed, a strong wish to learn, great hopes and aspirations, learning rewards, and supportive learning environments (Dornyei, 1994). Motivation to learn is important to identify in order to strengthen the learning process itself, especially in the following substances: determining the strengthening of learning, clarifying learning goals, and determining discipline (Jordan, 1993). In general, this learning motivation is divided into two types, namely intrinsic and extrinsic motivation. Intrinsic motivation is more likely to be an encouragement from within the individual who is strong to achieve something including positive attitudes and mentality that is formed due to stimuli from within him/herself. On the other hand, extrinsic motivation is positive learning attitudes and mentality that are formed because of an external drive. Of course, both have very crucial roles in shaping students' personalities in achieving EAP learning success (Dornyei, 1994).

In short, comprehensive need analysis can determine the success of EAP learning because it yields the depth and breadth of EAP teaching materials, methods, media, and evaluation formats.

\section{METHOD}

This study aims to identify learning experiences, and motivation, and the needs of students to learn EAP in industrial engineering at two universities namely University of Muhammadiyah and University of PGRI Ronggolawe Tuban.

This study uses a mix method of quantitative and qualitative design because it uses numerical data and descriptions. Quantitative data is the identification of surveys used to map needs analysis, learning experience, and also learning motivation using closed questionnaires. Qualitative data is in the form of descriptions and findings of narratives 
that support quantitative data including opinions from interviews with stakeholders, especially lecturers and heads of study programs in two faculties.

The data has been taken from 40 (forty) students) and 8 (eight) lecturers in the Industrial Engineering faculty where the study program is applying English for Academic Purpose (EAP). The profiles of students as respondents are 18 female and 22 male, their age ranges from 20 to 23 where the age of 20 ( 5 respondents), 21 (24 respondents), 22 (8 respondents), and 23 (3 respondents). All these students are programming English for Academic Purposes (EAP) in semester 1 and 2 in that 32 of them are from urban and 8 are from rural areas. Their languages of common use are Bahasa Indonesia (Indonesian Language) and Bahasa Jawa (Javanese Language).

Table 1

Respondents' Profiles of Students

\begin{tabular}{ll}
\hline Items & Description \\
\hline Sex & 18 female, \\
& 22 male \\
\hline Age range & 20 (5 respondents), \\
& 21 (24 Respondents), \\
& 22 (8 respondents), \\
& 23 (3 respondents) \\
\hline Education level & Freshmen students \\
\hline Social status & 32 urban, \\
& 8 rural \\
\hline Language of common use & Bahasa Indonesia, Javanese language \\
\hline
\end{tabular}

There are three types of questionnaires developed to obtain data, namely closed and opened open ended questionnaires about needs analysis that identified two main purposes namely target needs and learning needs, closed ended questionnaires about student learning experiences, and closed ended questionnaires about student learning motivation. In addition, to complete the questionnaires, interviews were used to gather data from lecturers and study program leaders.

The first questionnaire deals with learning experience which contains questions about learners' perceptions of the interaction of individuals with the environment in which he responds to all stimuli that comes. Learning interactions with external environment consist of interactions with the material in items 1,2 and 3, while the interaction with the strategies in items 4, 5, 6, and 7. Furthermore, students' responses are divided into two, namely student attitudes toward learning processes that have been experienced in items $8,9,10$, and 11 , while student attitudes toward fellow students on items 12,13 , 14, and 15. Furthermore, each item has been examined through Pearson productmoment validation test with the results as follows calculated $\mathrm{r}$ on item 1 amounting to 0.804 , item 2 is 0.528 , item 3 is 0.704 , item 4 is 0.562 , item 5 is 0.634 , item 6 is 0.471 , item 7 is 0.713 , item 8 is 0.505 , item 9 is 0.472 , item 10 is 0.526 , item 11 is 0.346 , item 12 is 0.396 , item 13 is 0.682 , item 14 is 0.506 , and item 15 is 0.504 . It can be seen that the calculation of the 15 items shows the number of calculated $r$ above 0.3 meaning that all the items have been considered valid. The results of the reliability calculation using 
Crobach Alfa show 0.841 where this result is greater than 0.6 so that all items have also been considered reliable.

The second questionnaire about achievement motivation which is aimed at identifying student motivation to succeed in learning. There are two important aspects that are measured, namely the drive for achievement consists of goals in items 1, 2, selfconfidence in items 3,4 , competition, items $5,6,7$, pride on items 8,9 , and the next is an effort to achieve namely accepting assignments on items 10,11, responsibility for items 12,13 , and willingness to accept risks in items 14,15 . The results of this validity analysis show calculated $\mathrm{r}$ of each item are as follows; item 1 is 0.764 , item 2 is 0.809 , item 3 is 0.677 , item 4 is 0.803 , item 5 is 0.509 , item 6 is 0.726 , item 7 is 0.478 , item 8 is 0.579 , item 9 is 0.710 , item 10 is 0.674 , item 10 is 0.674 item 11 is 0.678 , item 12 is 0.586 , item 13 is 0.758 , item 14 is 0.524 , and item 15 is 0.656 . The results of the analysis validity using the Pearson product-moment is above 0.3 , which means that all items are classified as valid.

The next step is to find the relationship between learning experience and learning motivation by using Spearman Rank because the data collected is in the form of intervals that use ranges of 1 to 5 . The results of the study are considered to be strongly predicted if the correlation results above 0.3 or which are close to 1 and are considered to be weak correlated if the score is below 0.3 .

The third, needs analysis questionnaire was developed with reference to two objectives, namely identifying target needs in the form of learning objectives, language skills, material scope, etc., and learning needs consisting of strategies, interaction models, media, and evaluation of learning. This questionnaire was developed into 20 (twenty) items that are open ended questionnaire. This questionnaire was validated in content by looking at the depth and breadth of the question items in accordance with the guidelines of Hutchinson and Waters (1987) who had already developed two areas of these needs into more detailed follow-up questions.

The results of the research that have been analyzed are then used as input to produce draft of materials in the form of a prototype that is ready to project syllabus or learning materials into applicable sequences in each chapter delivery.

\section{FINDINGS}

\section{Results of Identification of Learning Experiences}

The learning experience has been identified by using a questionnaire that describes the interaction of students with the learning process and the external environment (items 1 to 7), as well as attitudes to learning and behavior (items 8 to 15). Using a scale of 1 (very less) to 5 (strongly agree), respondents were asked to respond to each of these items according to their experience of learning English so far. The identification results are described in the following sections: 
Table 2

$\underline{\text { Results of Learning Experiences }}$

\begin{tabular}{|c|c|c|c|c|c|c|}
\hline No. & Item & $\mathrm{N}$ & Min & Max & Mean & $\begin{array}{l}\text { Std. } \\
\text { Deviation }\end{array}$ \\
\hline$\overline{1}$ & $\begin{array}{l}\text { Receptive mastery (listening and reading) is an ability that is very difficult to } \\
\text { master. }\end{array}$ & 40 & 2.00 & 5.00 & 3.1000 & .77790 \\
\hline 2 & Productive mastery of skills (writing and speaking) is a very difficult ability. & 40 & 2.00 & 4.00 & 3.1500 & .73554 \\
\hline$\overline{3}$ & I don't like learning on receptive skills. & 40 & 2.00 & 4.00 & 2.8500 & .57957 \\
\hline 4 & I am easier to understand the material of productive skills. & 40 & 2.00 & 4.00 & 3.0500 & .74936 \\
\hline 5 & I am not bored with the learning strategies I ever followed. & 40 & 2.00 & 4.00 & 2.9500 & .59700 \\
\hline 6 & I prefer learning interactions that are dynamic and often involve st & 40 & 2.00 & 4.00 & 3.1000 & .77790 \\
\hline 7 & I am more pleased with the model of discussion and presentation. & 40 & 2.00 & 4.00 & 3.1000 & .54538 \\
\hline 8 & I have difficulty mastering learning without understanding the learning goals. & 40 & 2.00 & 4.00 & 3,0000 & .64051 \\
\hline 9 & Teachers who are able to use various learning media help me more. & 40 & 2.00 & 5.00 & 3,0000 & .78446 \\
\hline 10 & Friendly and disciplined teachers encourage me to be better at learning. & 40 & 2.00 & 4.00 & 3.1500 & .66216 \\
\hline 11 & Teachers who master the material make it easier for me to learn. & 40 & 2.00 & 5.00 & 3.1000 & .77790 \\
\hline$\overline{12}$ & $\begin{array}{l}\text { If there are friends who are smarter in learning, I feel motivated to participate } \\
\text { in trying better. }\end{array}$ & 40 & 2.00 & 4.00 & 3.2000 & 68687 \\
\hline$\overline{13}$ & $\begin{array}{l}\text { If there are friends who cannot master the learning material I always try to } \\
\text { help. }\end{array}$ & 40 & 2.00 & 5.00 & 3.1500 & .73554 \\
\hline 14 & If I master more material, I always share with colleagues. & 40 & 2.00 & 5.00 & 3.3000 & .85335 \\
\hline \multirow[t]{2}{*}{$\overline{15}$} & $\begin{array}{l}\text { The attitude of a good colleague helps me more to facilitate my learning } \\
\text { process. }\end{array}$ & 4 & 2.00 & 3.00 & 2.7500 & 853 \\
\hline & Average & 40 & 2 & 4.2 & 3.06 & 0.7 \\
\hline
\end{tabular}

The data above illustrates that the learning experience of students is in a reasonable position (average 3) which means that students have neutral experience in learning languages previously, implying that they experience preceding normal learning. This data also shows that no disturbing experience or unsuccessful English learning of students, so it is easier for the ESP learning designer to offer tolerable learning strategies.

\section{The Results of the Identification of Achievement Motivation}

Achievement motivation was identified by using a questionnaire consisting of 15 items about encouragement in achievement (items 1 to 9) and achievement to process (items 10 to 15 ). Respondents were also asked to respond to their choices using scale 1 (highly disagree) and 5 (strongly agree) according to their preferences. The results of the identification are all described in the following sections:

Table 3

Results of Achievement Motivation

\begin{tabular}{|c|c|c|c|c|c|c|}
\hline No. & Item & $\mathrm{N}$ & Min & Max & Mean & $\begin{array}{l}\text { Std. } \\
\text { Deviation }\end{array}$ \\
\hline 1. & I want to achieve high English values & 40 & 3.00 & 5.00 & 3.9000 & .54538 \\
\hline 2. & I want to try hard to get the best rank in the class & 40 & 3.00 & 5.00 & 3.6500 & .57957 \\
\hline 3. & I am sure I can achieve the highest score in English lessons & 40 & 3.00 & 5.00 & 3.6750 & .61550 \\
\hline 4. & I am sure I can achieve higher achievements than other friends & 40 & 3.00 & 5.00 & 3.9000 & .63246 \\
\hline 5. & I am able to do the tasks given by the teacher as well as possible. & 40 & 3.00 & 5.00 & 3.7250 & .59861 \\
\hline 6. & I feel able to compete to get maximum results in English lessons. & 40 & 3.00 & 5.00 & 3.6500 & .57957 \\
\hline 7. & I always do assignments given by the teacher without the help of friends. & 40 & 3.00 & 5.00 & 3.7250 & .64001 \\
\hline 8. & Achieving high grades is a pride for me & 40 & 3.00 & 5.00 & 3.5000 & .59914 \\
\hline 9. & I am happy if someone else congratulates me on my achievements & 40 & 3.00 & 5.00 & 3.5500 & .59700 \\
\hline 10 & I am always passionate about facing challenges in learning & 40 & 3.00 & 5.00 & 3.7250 & .55412 \\
\hline 11. & I will carry out school tasks as well as possible & 40 & 3.00 & 5.00 & 3.7000 & .64847 \\
\hline
\end{tabular}

International Journal of Instruction, July $2019 \bullet$ Vol.12, No.3 


\begin{tabular}{lllllll}
\hline 12. & I will be responsible for all actions that I do at school. & 40 & 3.00 & 5.00 & 3.8750 & .56330 \\
\hline 13 & $\begin{array}{l}\text { I will work on the questions given by the teacher during the exam } \\
\text { without the help of others }\end{array}$ & 40 & 3.00 & 5.00 & 3.8750 & .72280 \\
\hline 14 & $\begin{array}{l}\text { I am worried that the achievements that I have obtained at this time } \\
\text { cannot be maintained }\end{array}$ & 40 & 3.00 & 5.00 & 3.7250 & .55412 \\
\hline 15. & $\begin{array}{l}\text { Failure to achieve learning achievements will not weaken my enthusiasm } \\
\text { to continue learning }\end{array}$ & 40 & 3.00 & 5.00 & 3.6250 & .70484 \\
\hline Average & 40 & 3 & 5 & 3.7 & 0.6 \\
\hline
\end{tabular}

The data above shows that learners' achievement motivation is in the range of numbers 3.7 approaching number 4 or moderate towards strong. This shows that learner achievement motivation is good and strong, entailing the desired learning motivation at the time before starting ESP learning requires more encouragement especially when following the learning process to be upgraded to level 5 or very strong. Motivation to learn is indeed up and down along the experience of the learning process faced both before and during the learning process takes place. This data encourages teachers to continuously commit to always improve student learning motivation by optimizing strategy services and interesting learning media.

\section{The Results of the Correlation between Learning Experience and Achievement Motivation}

To ascertain whether the predicted learning experience correlates significantly with achievement motivation toward prospective of EAP learners, the Spearman rho correlation test is used to analyze the following findings:

Table 4

Result of Correlation

\begin{tabular}{lllll}
\hline \multirow{3}{*}{ Spearman's rho } & & & VAR00004 & VAR00005 \\
\cline { 3 - 5 } & VAR00004 & Correlation Coefficient & 1,000 & .135 \\
\cline { 2 - 4 } & & Sig. (2-tailed) &. & .407 \\
\cline { 2 - 4 } & $\mathrm{N}$ & Correlation Coefficient & .135 & 40 \\
\cline { 2 - 4 } & VAR00005 & Sig. (2-tailed) & .407 & .000 \\
\cline { 3 - 5 } & & $\mathrm{N}$ & 40 & 40 \\
\hline
\end{tabular}

The data shows that the correlation coefficient is 0.135 which is far below 0.3 , which means that the correlation predictions are very weak and very low. Thus for respondents with the above characters have not provided strong support for predicting the correlation between learner experience and achievement motivation for the prospective of EAP learners.

\section{Results of Need Analysis from Students}

The subjects of need analysis are 40 (forty) students from two institutions, namely industrial engineering study programs from University of Muhammadiyah Gresik and University of PGRI Ronggolawe Tuban. The results show that English skills are generally in the post-elementary position $(55 \%)$ and the pre-intermediate $(23 \%)$, the rest spread to elementary and intermediate. Specifically, the purpose of their English language learning is to be successful in studies and also in careers at work $(68 \%)$. Speaking $(82 \%)$ is very dominant and yet their speaking frequency is classified as rare $(48 \%)$ and rarely (29\%), meaning that there are still gaps between high expectations and 
actual language skills where they often talk with friends (23\%) and teachers $(48 \%)$ and both of them (29\%).

In terms of reading, their reading sources are books (78\%), journals (7\%), and both are from two sources of books and journals as reading at the same time (15\%). While the frequency of writing is still very rare (24\%), rarely (39\%), quite often $(32 \%)$, often $(5 \%)$. They often write letters $(50 \%)$, articles $(19 \%)$ and often write for their secondary purpose is $31 \%$, this explanation is illustrated in the following table 5 .

Table 5

Description of Aims and Resources

\begin{tabular}{|c|c|c|c|c|c|c|}
\hline No. & Item & Std & work & study & both of them & responses \\
\hline 1 & The aim of English learning & 10.14 & $\begin{array}{l}7 \\
17 \% \\
\end{array}$ & $\begin{array}{l}6 \\
15 \% \\
\end{array}$ & $\begin{array}{l}27 \\
68 \% \\
\end{array}$ & 40 \\
\hline \multirow{3}{*}{2} & \multirow{3}{*}{$\begin{array}{l}\text { Mastery skills should be in } \\
\text { priority }\end{array}$} & \multirow{3}{*}{13.96} & speaking & reading & writing & \multirow{3}{*}{40} \\
\hline & & & 33 & 5 & 2 & \\
\hline & & & $82 \%$ & $13 \%$ & $5 \%$ & \\
\hline \multirow{3}{*}{3} & \multirow{3}{*}{$\begin{array}{l}\text { To whom they often speak } \\
\text { English }\end{array}$} & \multirow{3}{*}{3.86} & teacher & friends & both of them & \multirow{3}{*}{40} \\
\hline & & & 19 & 9 & 12 & \\
\hline & & & $48 \%$ & $23 \%$ & $29 \%$ & \\
\hline \multirow{3}{*}{4} & \multirow{3}{*}{ Resources they read often } & \multirow{3}{*}{13.02} & book & journaling & both of them & \multirow{3}{*}{40} \\
\hline & & & 32 & 2 & 6 & \\
\hline & & & $78 \%$ & $7 \%$ & $15 \%$ & \\
\hline \multirow{3}{*}{5} & \multirow{3}{*}{ Resources they usually write } & \multirow{3}{*}{4.55} & letter & article & both of them & \multirow{3}{*}{40} \\
\hline & & & 20 & 8 & 12 & \\
\hline & & & $50 \%$ & $19 \%$ & $31 \%$ & \\
\hline
\end{tabular}

In terms of listening, students stated very often (1\%), often (8\%), rarely (53\%), very rare $(29 \%)$, and very very rarely $(8 \%)$. In general, they listen to material in the form of English in the form of movies (42\%), English TV (8\%), and always hear both TV and movie at the same time by $50 \%$ as explained in the following table 6 .

Table 6

Listening Resources

\begin{tabular}{|c|c|c|c|c|c|c|c|}
\hline No. & Item & Std & tv & radio & film & all of them & responses \\
\hline \multirow[t]{2}{*}{6} & \multirow[t]{2}{*}{ Resources they listen to English from } & & 5 & 0 & 16 & 19 & \multirow[t]{2}{*}{40} \\
\hline & & & $8 \%$ & $0 \%$ & $\begin{array}{l}42 \\
\%\end{array}$ & $50 \%$ & \\
\hline
\end{tabular}

Furthermore, in terms of learning methods they like are by optimizing information technology (39\%), discussion and positive interactions with achievements (16\%), and through explanation only by $6 \%$ and those who combine all three at $39 \%$.

Table 7

Listening Methods

\begin{tabular}{|c|c|c|c|c|c|c|c|}
\hline No. & Item & Std & Explanation & $\begin{array}{l}\text { interactive } \\
\text { discussion } \\
\text { and presentation }\end{array}$ & $\begin{array}{l}\text { using } \\
\text { technology } \\
\text { information }\end{array}$ & $\begin{array}{l}\text { all of } \\
\text { them }\end{array}$ & responses \\
\hline \multirow[t]{2}{*}{7} & \multirow{2}{*}{$\begin{array}{l}\text { Learning methods they } \\
\text { like }\end{array}$} & \multirow[t]{2}{*}{5.68} & 3 & 7 & 15 & 15 & \multirow[t]{2}{*}{40} \\
\hline & & & $6 \%$ & $16 \%$ & $39 \%$ & $39 \%$ & \\
\hline
\end{tabular}

Students also hope that the field of work expected during and after obtaining English language training is industry, business, and service (19\%), academic and education 
(42\%), and which aims for both purposes, for academic interests and industrial interests $\%$ (explained in table 8)

Table 8

Field of Work

\begin{tabular}{|c|c|c|c|c|c|c|}
\hline No. & Item & Std & $\begin{array}{l}\text { Industry, } \\
\text { Business } \\
\text { and Service }\end{array}$ & $\begin{array}{l}\text { Academic } \\
\text { and } \\
\text { education }\end{array}$ & $\begin{array}{l}\text { both } \\
\text { of } \\
\text { them }\end{array}$ & responses \\
\hline 8 & Field of work they expect & 4.03 & $\begin{array}{l}8 \\
19 \%\end{array}$ & $\begin{array}{l}17 \\
42 \%\end{array}$ & $\begin{array}{l}15 \\
39 \%\end{array}$ & 40 \\
\hline
\end{tabular}

In terms of future expectations about the usefulness of English in the future, students state that English will be used in discussions and seminars (32\%), reading and writing journal articles, research reports, letters and books (5\%), communication with friends and colleagues (8\%), and those who expect a combination of these are 55\% (explained in table 9).

Table 9

Future Expectations

\begin{tabular}{|c|c|c|c|c|c|c|c|}
\hline No. & Item & Std & $\begin{array}{l}\text { Speak and listen English } \\
\text { by phone, face to face, } \\
\text { discussion, seminar, etc. }\end{array}$ & $\begin{array}{l}\text { read and write English } \\
\text { on } \\
\text { article, journal, report, } \\
\text { letter and book }\end{array}$ & $\begin{array}{l}\text { communication } \\
\text { with the colleague, } \\
\text { friends, and other }\end{array}$ & $\begin{array}{l}\text { all } \\
\text { of } \\
\text { them }\end{array}$ & responses \\
\hline \multirow[t]{2}{*}{9} & \multirow[t]{2}{*}{$\begin{array}{l}\text { The expectation of } \\
\text { English for future }\end{array}$} & \multirow[t]{2}{*}{7.7} & 12 & 3 & 4 & 21 & \multirow[t]{2}{*}{40} \\
\hline & & & $32 \%$ & $5 \%$ & $8 \%$ & $55 \%$ & \\
\hline
\end{tabular}

The interest in learning English from students namely watching TV and movies (30\%), listening to music and radio (13\%) traveling and social culture (19\%) reading (3\%), and those who are interested in all these interests is $35 \%$ (explained in table 10).

Table 10

English Interests

\begin{tabular}{llllllllll}
\hline No. Item & Std & $\begin{array}{l}\text { watching } \\
\text { and movie }\end{array}$ & $\begin{array}{l}\text { listening to } \\
\text { music and } \\
\text { radio }\end{array}$ & $\begin{array}{l}\text { traveling and } \\
\text { social culture }\end{array}$ & reading & all of them & responses \\
\hline 10 & $\begin{array}{l}\text { The interest } \\
\text { their English }\end{array}$ & of & 4.27 & $\begin{array}{l}11 \\
30 \%\end{array}$ & 6 & 8 & 2 & 13 & 40 \\
\hline
\end{tabular}

The results of the analysis of student needs above indicate that they have target needs related to the pre-intermediate level of English language skills, speaking which tends to be desired mostly, least frequency in using skills, interactive learning models are their desires or interests that they are interested in, and business and works experiences are expectations in using English especially when they finish learning. Likewise, this needs analysis identifies their learning needs, namely with regard to the desire for enjoyable and supportive learning atmosphere, interesting learning strategies, various learning resources, and also interactive teaching media they really want.

\section{Results of Need Analysis from Teaching Staff}

This section presents the findings of the needs analysis of the instructors from the open ended questionnaire to eight teaching staff. There are seven focuses that are collected, namely the profile of graduate students, the purpose of learning English in study 
programs of the two faculties, the scope of English learning materials, appropriate learning methods, learning media needed, study materials that require language English, and general advice so that learning English can work well.

Regarding the profile of industrial engineering graduates, it is to strengthen the profile of ideal graduates $(12 \%)$, supports the scientific mastery of study programs and also simultaneously strengthen the profile of graduates $(88 \%)$. As explained in Table 11 below.

Table 11

The Purposes

\begin{tabular}{|c|c|c|c|c|c|c|}
\hline $\begin{array}{l}\text { The purpose of } \\
\text { learning English }\end{array}$ & $\begin{array}{l}\text { To strengthen the } \\
\text { learning outcome } \\
\text { ideal }\end{array}$ & $\begin{array}{l}\text { To support the body } \\
\text { of knowledge }\end{array}$ & Both are important & $\begin{array}{l}\text { Standard } \\
\text { Deviation }\end{array}$ & $\begin{array}{l}\text { Res } \\
\text { se s }\end{array}$ & pound \\
\hline & $1(12 \%)$ & $0(0 \%)$ & $7(88 \%)$ & 3.09 & & 8 \\
\hline
\end{tabular}

Next is related to the scope of the material in learning English where English material must be in accordance with the basic courses in the study program $(25 \%)$ and also a combination of general English material and at the same time in accordance with the basic courses in the study program (75\%) table 12 as follows.

Table 12

The Scope of Materials

\begin{tabular}{llcccc}
\hline $\begin{array}{l}\text { The scope of } \begin{array}{l}\text { Therials support } \\
\text { materials } \\
\text { learning English }\end{array} \\
\text { of }\end{array}$ & $\begin{array}{l}\text { Toneral English } \\
\text { fundamental } \\
\text { courses }\end{array}$ & $\begin{array}{l}\text { Both are needed } \\
\text { materials }\end{array}$ & $\begin{array}{l}\text { Standard } \\
\text { Deviation }\end{array}$ & $\begin{array}{l}\text { Res } \\
\text { pound } \\
\text { se s }\end{array}$ \\
\cline { 2 - 7 } & $2(25 \%)$ & $0(0 \%)$ & $6(75 \%)$ & 2.49 & 8 \\
\hline
\end{tabular}

The method of learning English in accordance with the study program is communicative learning (12\%), a combination of lecture methods, student-centered, and communicative methods $(88 \%)$ with the description in table 13 as follows.

Table 13

Expectation of Teaching Methods

\begin{tabular}{|c|c|c|c|c|c|c|}
\hline $\begin{array}{l}\text { The suitable } \\
\text { teaching } \\
\text { methods to }\end{array}$ & $\begin{array}{l}\text { Learner } \\
\text { center } \\
\text { methods }\end{array}$ & $\begin{array}{l}\text { Communicative } \\
\text { teaching methods }\end{array}$ & Explanations & $\begin{array}{lr}\text { Those } & \text { three } \\
\text { teaching methods } \\
\text { are needed }\end{array}$ & $\begin{array}{l}\text { Standard } \\
\text { Deviation }\end{array}$ & $\begin{array}{l}\text { Res } \\
\text { pound } \\
\text { se s } \\
\end{array}$ \\
\hline apply & $0(0 \%)$ & $1(12 \%)$ & $0(0 \%)$ & $7(88 \%)$ & 2.92 & 8 \\
\hline
\end{tabular}

Based on the findings, the required and effective learning media is a combination of Android-based, computer assisted, and audio-visual (100\%) according to the description in table 14 as follows.

Table 14

Expectation of Teaching Media

\begin{tabular}{|c|c|c|c|c|c|c|c|}
\hline \multirow[t]{2}{*}{$\begin{array}{l}\text { The effective } \\
\text { media }\end{array}$} & teaching & $\begin{array}{l}\text { Audio } \\
\text { Visual }\end{array}$ & $\begin{array}{l}\text { Assisted } \\
\text { computer } \\
\text { media }\end{array}$ & $\begin{array}{l}\text { Android } \\
\text { based } \\
\text { media }\end{array}$ & $\begin{array}{lr}\text { Those } & \text { three } \\
\text { media } & \text { are } \\
\text { needed } & \end{array}$ & $\begin{array}{l}\text { Standard } \\
\text { Deviation }\end{array}$ & $\begin{array}{l}\text { Res } \\
\text { pound } \\
\text { se s }\end{array}$ \\
\hline & & $0(0 \%)$ & $0(0 \%)$ & $0(0 \%)$ & $8(100 \%)$ & 3.46 & 8 \\
\hline
\end{tabular}

The next section is an overview of study materials and its scope that requires English competence. The field of industrial engineering contains English for the industry, industrial management, and large, medium and small industrial governance. 
Overall the suggestions that come are the need to increase the number of credits, focus on habituating oral and written communication rather than grammar, the importance of conversational tutorial videos and English pronunciation tutorials easily and varied, applied English, intensive coordination between English teachers and lecturers at the study program.

\section{Prototype}

From the summary of the three types of questionnaires above, a general description of the results of ESP learners' needs analysis for industrial engineering students can be described in the summary of the prototype findings as follows:

Table 15

Prototype of EAP in Industrial Engineering

\begin{tabular}{|c|c|}
\hline \multicolumn{2}{|l|}{ Audience } \\
\hline The level of students' ability in English & Intermediate Pre \\
\hline Interest & Study and works \\
\hline Motivation & Medium to High \\
\hline Learning Experience & Good and positive learning experiences \\
\hline \multicolumn{2}{|l|}{ AIMS } \\
\hline Skills of English & Speaking is dominant \\
\hline Integrated skills & Integrated skill is Required \\
\hline \multicolumn{2}{|l|}{ Content } \\
\hline Language descriptions & Daily to academics language descriptions \\
\hline Structural & Simple to complicated sentences \\
\hline Functional & Academic learning environment \\
\hline Combinations & English for academic purposes \\
\hline \multicolumn{2}{|l|}{ Language Points } \\
\hline Particular Structures & Sentence developments tenses, conditional sentences, etc. \\
\hline Vocabulary areas & Industrial engineering \\
\hline \multicolumn{2}{|l|}{ Content organization } \\
\hline \multicolumn{2}{|c|}{ Language points related to receptive and productive skills } \\
\hline \multicolumn{2}{|c|}{ Subjects for industrial engineering issues, quality control, operational, industrial plants, consultants, etc. } \\
\hline \multicolumn{2}{|c|}{ All topics are delivered more easily to more difficult formats } \\
\hline \multicolumn{2}{|c|}{ Methodology } \\
\hline \multicolumn{2}{|l|}{ Kinds of Exercises } \\
\hline \multicolumn{2}{|l|}{ Guided to free activities } \\
\hline \multicolumn{2}{|l|}{ Comprehension of production } \\
\hline \multicolumn{2}{|l|}{ Objective answers } \\
\hline \multicolumn{2}{|l|}{ Subjective answers } \\
\hline \multicolumn{2}{|l|}{ Problem-solving } \\
\hline \multicolumn{2}{|l|}{ Role-play, simulations, drama, games } \\
\hline \multicolumn{2}{|l|}{ Learning Techniques } \\
\hline \multicolumn{2}{|l|}{ Pair work } \\
\hline \multicolumn{2}{|l|}{ Small group work } \\
\hline \multicolumn{2}{|l|}{ Student presentation } \\
\hline \multicolumn{2}{|l|}{ Technical subject-matter } \\
\hline \multicolumn{2}{|l|}{ Others } \\
\hline \multicolumn{2}{|l|}{ Aids } \\
\hline \multicolumn{2}{|l|}{ Tape-Recorders } \\
\hline \multicolumn{2}{|l|}{ Mobile phones } \\
\hline \multicolumn{2}{|l|}{ Videos, computers } \\
\hline Combinations of means are computers, & d mobile-assisted learning \\
\hline
\end{tabular}

The results of the identification of the prototype above are then developed into each chapter of teaching material for English for Academic Purposes for Industrial 
Engineering students. Each chapter is arranged in the following instruction; (1). Knowledge building (serves to prepare students' knowledge to be able to start discussing the content of the material in each chapter with simple relevant themes), (2). Listening activities (listening activities with a focus on understanding information and language development, vocabulary building, exercises for transferring information and reinforcing the process of understanding material, (3). Reading activities (developing reading comprehension and building vocabulary, transfer of reading information comprehension through discussion and group work), (4). Speaking activities (developing speaking skills and building vocabulary, recognizing and remembering language expressions in certain situations, developing the ability to transfer information through dialogue, role play, games, discussions, presentations, and joint projects), and (5). Writing activities (developing simple to advanced writing skills begins with filling in puzzles, arranging jumble sentences and paragraphs, transferring product development of sentences and paragraphs in the form of presentations and small discussions to prepare good paragraph writing reports).

\section{DISCUSSION}

Needs analysis is an important first step to designing appropriate language training to help students absorb knowledge in their field of study (Alastal, 2012). To optimize needs analysis, the more intensive collaboration between providers of language education, academic departments, and professionals in the workplace is needed to facilitate the design and implementation of effective EAP training. The research data presented by Chan and Chen has shown that proper alignment of subject content with aspects of English language needs helps the learning and teaching process more effective. On the contrary, discrepancies in the focus of assessment and learning arrangements affect student satisfaction (Chan \& Chen, 2012).

In general, learning needs are divided into two major aspects, namely the target needs and learning needs themselves (Hutchinson \& Waters, 1987). Elachachi and Graia make it clear that learning needs can be classified into three important things, namely psychological and cognitive needs (recreational, motivational, and emotional needs), sociological needs (teacher's role and social responsibility), and methodological needs (techniques, strategies, methods) (Hamzaoui-Elachachi \& Graia, 2014).

The study of EAP learning needs analysis has of course been carried out by many researchers including Christison and Krahnke who have conducted research on English language needs on three important things, namely the desired English skills, learning experience, and their opinions on teachers (Christinson \& Krahnke, 1986). Likewise, Clowes has conducted a special needs analysis of perceptions of the use of language functions and the underlying reasons in the world of industry (Clowes, 1994) and Howells about Chinese learners, and Jordan (1993) about the difficulties of foreign students in the UK (Howell, 1995).

Just comparing the findings of the needs analysis that has been done by experts suggests that the results of the analysis of needs always vary depending on the characteristics and specifications of the field of study. In his research findings, Thi Hong stated that the 
acquisition of speaking skills in EAP learning by students was preferred over listening skills. This is due to the fact that when students listen, they must understand the meaning when the message is being heard and they must anticipate the next message (Thi Hong, 2018). When they lose a significant part of the message, they have difficulty responding to questions related to the limitations of the portion to adequately follow the process. My Lien (2009) identified perceptions of EAP presentations and the results showed that many students had difficulties in presentation skills especially in terms of material selection, content, and presentation format. Students' attitudes towards EAP presentations vary according to the context and needs (My Lien, 2009). This can be possible because each context has a different scope and gap in the field of science.

In general, the development of science and technology has influenced the shifting findings of EAP learners' needs. Based on the latest reports, the EAP learning success system is the optimal role of technology in learning, especially in determining learning resources and learning processes. EAP education policymakers in this case really need to pay attention to this because they are the parties that have the highest authority and determination to organize EAP better (Dashtestani \& Alavi , 2014). The use of technology that facilitates EAP learning has also been examined by Estaji (2018) about the role of the Wiki in learning through the study of the experiments he did especially in writing learning. Learning by using this webpage has many advantages including fast and more efficient, high time effectiveness, all processes can be monitored because all activities are recorded well and neatly so as to reduce learning anxiety (Estaji, 2018). Integrating the use of technology in English instruction will answer the needs of specific English language proficiency of engineering students. Because the highest percentage of respondents believe that the use of technology will help them learn better in mastering English, it is important for English teachers to integrate the use of technology in designing an English curriculum for Engineering students (Machmud, 2018).

In addition to cognitive and methodological aspects as an important part of needs analysis, the affective aspects of learning especially regarding the learning experience and learning motivation of EAP students must also be an important concern. These last two are rarely touched by the researchers in the field of the analysis of the needs of EAP, but the mapping will identify findings of the learning experience and motivation to learn can help the accuracy of the findings of a need analysis as a whole. Some studies have emerged and are partial, for example by Elachachi and Graia (2012) which states that the motivation to learn EAP by Biomedical Engineering students is very low because of lack of English language skills, learning materials and inaccurate English methods, and unpleasant class situations. This finding is also supported by Johnson (2012) that most engineering majors do not have time to commit or are less motivated in learning English because of the academic demands of their engineering program. The lack of motivation to learn because they also allow the low level of proficiency in learning their English (Johnson, 2012).

Almost all studies of needs analysis have used similar instruments, namely questionnaires and interviews to learners and education providers. From the views and results of research on needs analysis, it can be concluded that all agree: (1) Need 
analysis is the first important step in the EAP design as an important stage that determines the color and weight of the syllabus, material, and learning strategies that will be developed and to determine success for the next process; (2). Needs analysis provides a special portrait of the expectations and desires of the learning group in a particular field so that any results of this need analysis cannot be generalized to the needs of other groups; (3). Given the needs of learners who are very dynamic along with the development and demands of civilization that is increasingly fast, then the analysis of needs should be carried out periodically and sustainably and objectively as well; (4). Incorporating affective factors into needs analysis is a good prospect to produce an analysis output which represents more comprehensive evidence so that it can help detect changes in learners' desires that are constantly changing from time to time.

\section{CONCLUSION}

This study identifies EAP requirements for Industrial Engineering study programs in three important points, namely learning experience, achievement motivation, and learning needs. Using three questionnaires to 40 students and 8 teachers in Industrial Engineering, it was found briefly two important general conclusions that (1) changes in EAP learning needs have increasingly shown a tendency to change the direction into English for Special Academic Purposes and (2) affective aspects (which are commonly ignored) are very determining points in every analysis of needs to strengthen comprehensive results. The conclusion is then detailed as follows; firstly, their learning experiences are quite worthy and no one has ever involved a preceding negative experience in learning English. Secondly, learning motivation is also classified as positive and tends to be strong so that it can be used as a good capital in developing classroom learning. In addition, learning experience has been predicted not quite strong enough to correlate with their learning motivation. Thirdly, the target needs of students display that their language skills were pre-intermediate $(78 \%)$ with the expected ability to speak (83\%), and the material scope led to successful learning and work. The learning needs of students especially of learning material refers to books and research articles that often come into contact with seminars and the publication of scientific papers in the field of industrial engineering with a combination of audio-visual learning media and information technology integration (cellular assisted language learning) so as to facilitate the implementation of student learning centers.

Certainly, this research is useful for prospective teachers and EAP material developers in industrial engineering that affective factors can be inserted wisely to the deeper identification of needs to result comprehensive prototype that strengthens the suitability of EAP materials and its strategy. Both of these affective factors are more interesting to study further, especially for EAP learners in other fields and with diverse subjects, to ensure their depth and breadth of influence in EAP teaching. This study also confirms that Academic EAP is increasingly strong towards English for Special Academic Purposes (ESAP). This shift towards a different pole is probably caused by a very dynamic need and much influenced by the learner's character so that the scope of EAP becomes very developed and diverse. This research is also expected to be continued to reassure the ESAP trend and also the importance of effective factors in ESP learning 
especially the correlation between learning experience and motivation to learn with new data and different fields of study.

\section{REFERENCES}

Alastal, A. A. (2012). Investigating the Academic English Language Target Needs of Undergraduates at the Faculty of Applied Science at Al-Aqsa University: Students' Perceptions. The Asian ESP Journal Summer Edition, 5-26. Retrieved from ttp://www.asian-esp.com

Alderson, J. C. (1980). A Process Aproach of Reading at The University of Mexico Project in Material Design. ELT Document Special, 134-163.

Anwar, K. (2015). A Constructive Teaching Model in Learning Research Concept for English Language Teaching Students. International Education Studies, 8(5). doi:10.5539/ies.v8n5p62

Anwar, K., \& Arifani, Y. (2016). Task Based Language Teaching: Development of CALL. International Education Studies, Vol. 9,(6). doi:http://dx.doi.org/10.5539/ies.v9n6p168

Asmara, C. H., Anwar, K., \& Ribeh, M. (2016). EFL Learners' Perception toward an Outdoor Learning Program. International Journal of Education \& Literacy Studies, 4(2). doi:http://dx.doi.org/10.7575/aiac.ijels.v.4n.2p.74

Berwick, R. (1989). Need Assessment; Language Programming: From Theory to Practice. In R.K Johnson (eds), The Second Language Curriculum, pp 48-62. New York: Cambridge University Press.

Brindley, C. (1989). The Role of Needs Analysis in Adult ESL Programme Design. (R. Johnson, Ed.) The Second Language Curriculum, 63-78.

Chan , F., \& Chen, J. (2012). An Impact Study on Alignment of Biomedical Engineering ESP with Content Subjects. ). he Asian ESP Journal Summer Edition, 8(2), 27-54. Retrieved from http://www.asian-esp-journal.com

Christinson, M., \& Krahnke, K. (1986). Student Perception of Academic Language Study. TESOL Quarterly, 20(1), 61-79.

Clowes, P. (1994). Learning What is the Language Need of Industry. Language Journal, 9, 22-25.

Conole, G. (2013). Designing for Learning in an Open World. New York: Springer.

Dashtestani, R., \& Alavi , S. M. (2014). . A Cross-Disciplinary Analysis of Higher Education Students' Perspectives on the Use of E-books for Learning Academic English. The Asian ESP Journal, 4-5. Retrieved from http://www.asian-esp-journal.com

Dornyei, Z. (1994). Motivation and Motivating in the Foreign Language Classroom. The Modern Language Journal, 78(3), 273-284. Retrieved from http://www.jstor.org/stable/330107 
Estaji, M. (2018). The Application of Wiki-Mediated Collaborative Writing as a Pedagogical Tool to Promote ESP Learners' Writing Performance. The Asian ESP Journal , 14(1), 112-141. Retrieved from http://www.asian-esp-journal.com

Hamzaoui-Elachachi, H., \& Graia, W. B. (2014). Motivation in the ESP Classroom: The Case of Algerian Biomedical Engineering students. The Asian ESP Journal, 71-98. Retrieved from http://www.asian-esp-journal.com

Howell, F. (1995). Chinese Language Learning: Student Need and Expectations: A Case Study. Babylon, 30(2), 22-27.

Hutchinson, \& Waters. (1987). English For Specific Purposes. New York: Cambridge University Press.

Johnson, M. P. (2012). Examining EFL Motivation in Japanese Engineering Students. The Asian ESP Journal Summer Edition, 8(2), 27-54. Retrieved from http://www.asianesp-journal.com

Jordan, R. (1993). Study Skills: Experience and Expectations. In M. Blue, Learn and Success: Studying Through English. London: Macmillion.

Kharma, N. (1988). ELF and Community Needs. IRAL, International Review of Applied Linguistics. XXXVI, I, 49-67.

Kuh, G. D. (2009). What student affairs professionals need to know about student engagement. Journal of College Student Development, 50(6), 683-706.

Machmud, K. (2018). Technology-Integrated ESP (English for Specific Purposes) Instructions: The Engineering Students' Perspectives. The Asian ESP Journal , 14(1). Retrieved from http://www.asian-esp-journal.com

My Lien, T. T. (2009). Assessing the Perceptions and Difficulties of Students at COT, VNU in Making ESP Presentations. The Asian ESP Journal, 5, 78-96. Retrieved from http://www.asian-esp-journal.com

Robinson, P. (1991). ESP Today. New York: Cambridge University Press.

Thi Hong, N. N. (2018). English for Specific Purposes Modules in Listening and Speaking for Dentistry students. The Asian ESP Journal, 386-412. Retrieved from http://www.asian-esp-journal.com

Widdowson, H. (1981). English for Specific Purposes:Criteria for Course Design, in L. Selinker at.al. (Eds), English for Academic and Technical Purposes: Studies in Honor of Louid Trimble, pp I-II. London: New Bury House. 